\title{
TOXICITY STUDIES DURING THE DEGRADATION OF PENTACHLOROPHENOL BY OZONATION IN THE PRESENCE OF $\mathrm{MnO}_{2} / \mathrm{TiO}_{2}$
}

\author{
CRISTINA QUISPE ${ }^{a, b, *}$, CRISTIAN VALDÉS ${ }^{a}$, ALVARO DELGADILLO ${ }^{c}$, \\ JORGE VILLASEÑOR ${ }^{a}$ JOSÉ CHEEL ${ }^{d}$, GINA PECCHI
}

\author{
${ }^{a}$ Laboratorio de Físico Química, Instituto de Química de Recursos Naturales, Universidad de Talca, Casilla 747, Talca, Chile. \\ ${ }^{b}$ Facultad de Ciencias de la Salud, Instituto de EtnoFarmacología (IDE). Universidad Arturo Prat, Casilla 121, Iquique 1110939, Chile. \\ ${ }^{c}$ Departamento de Química, Facultad de Ciencias, Universidad de La Serena, Casilla 599, Benavente 980, La Serena, Chile. \\ ${ }^{d}$ Laboratory of Algal Biotechnology-Centre ALGATECH, Institute of Microbiology of the Czech Academy of Sciences, Opatovický mlýn, Třebon̆. \\ ${ }^{e}$ Departamento de Físico Química, Facultad de Ciencias Químicas, Universidad de Concepción, Casilla 3-C, Concepción, Chile.
}

\begin{abstract}
Ozone is a strong oxidant used in the water treatment to remove organochloride compounds. Given that many processes of degradation generate chemical compounds that are more toxic than initial compounds, the development of optimized ozonation processes are required. In this study, pentachlorophenol (PCP) was used as a model of an organochlorine compound and the toxicity of its degradation products generated by both non-catalytic and catalytic ozonation processes were evaluated with a fresh-water Daphnia magna (ecotoxicity) and vegetables species Lactuca sativa and Panicum millaceum (Phytoxicity). The catalytic ozonation used $\mathrm{MnO}_{2} / \mathrm{TiO}_{2}$ as catalyst, which was characterized by X-ray diffraction analysis showing the presence of crystalline TiO ${ }_{2}$ phases, rutile and anatase. The specific BET surface area of $\mathrm{MnO}_{2} / \mathrm{TiO}_{2}$ was $43 \mathrm{~m}^{2} / \mathrm{g}$. It was found that the use of ozone as an oxidant showed a first order degradation rate constant $\left(\mathrm{k}_{\mathrm{obs}}=0.5 \pm 0.1 \mathrm{~min}\right.$ ${ }^{1}$ ). The uncatalyzed reaction showed several reaction intermediates like mono- and polychlorinated phenols, and quinones. The oxidation of these compounds led to low molecular weight organic acids. From these results, we proposed a pathway of PCP degradation using ozone. The catalyzed reaction showed a more potent effect in reducing the toxicity of the treated solution. Unlike the use of only ozone which does not decrease the toxicity. It was found that the treatment with catalytic ozonation decreases the toxicity of the solutions.
\end{abstract}

Keywords: Pentachlorophenol (PCP); catalytic ozonation; $\mathrm{MnO}_{2} / \mathrm{TiO}_{2}$; toxicity assays; Lactuca sativa; Panicum millaceum; Daphnia magna.

\section{INTRODUCTION}

Pentachlorophenol (PCP) has been used extensively as a broad-spectrum herbicide, as well as pesticide and wood preservative world-wide. ${ }^{1,2}$ PCP is toxic to both plants and animals; due to its high toxicity, $\mathrm{PCP}$ is ranked among the priority pollutant list of the US Environmental Protection Agency (EPA) in 1978, and it is classified as a Group B2, probable human carcinogen by the EPA., ${ }^{3,4}$ The PCP has a moderate solubility in water $(15 \mathrm{mg} / \mathrm{L})$, a rather high octanol-water constant $\left(\log K_{\text {ow }}=5.1\right)$ and very low concentration $(0.1$ $\mu \mathrm{g} / \mathrm{L}$ ), which can cause a deterioration of the ecosystem..$^{5}$ It is reported that the maximum concentration allowed should not exceed $0.055 \mathrm{mg} / \mathrm{L}$ in water surfaces. ${ }^{6}$

In Chile the manufacture, marketing and application of pesticides that contain PCP was prohibited according to the legislative decree $\mathrm{N}^{\circ} 78$ in 2004, however remediation processes are needed to destroy the remaining compound. Incineration is a common method to dispose waste organic compounds, but this process generates polychlorinated compounds like dibenzo- $p$-dioxins (PCDDs) ${ }^{7}$ and polychlorinated dibenzofurans (PCDFs) as by-products ${ }^{8,9}$ which are as toxic, carcinogenic and environmentally persistent. ${ }^{10,11}$ Therefore, it is of great importance to develop environmentally friendly techniques to eliminate PCP. Because of the toxic and recalcitrant nature of PCP, its degradation by traditional biological processes has not been satisfactory. So, it is highly recommended to seek removal methods for PCP degradation into less harmful intermediates, or even achieve its complete elimination by mineralization processes.

Due to various adverse effects of PCP, several physical and chemical techniques have been used to remove it from aqueous solutions. The use of advanced oxidation processes (AOP) in the treatment of industrial wastewater containing high concentrations of refractory compounds based on the generation of very reactive groups, particularly hydroxyl radicals have been carried out. Among these technologies, the $\mathrm{O}_{3}$ process is more efficient in pollutant degradation and less harmful to most living organisms compared to other oxidizing reagents like $\mathrm{H}_{2} \mathrm{O}_{2}$ or chlorine. ${ }^{12,13,14}$

Ozone is a very strong oxidant, but single ozonation process performance is not strong enough to remove the organic matter by mineralization because some oxidative reactions are relatively slow and selective. During the process of ozonation, the concentration of the substrate vanishes, but this is not indicative of the mineralization of the reactant, and the different products generated as intermediate compounds may be even more toxic than the initial pollutant. ${ }^{15,16}$ Nowadays, AOPs have been studied to provide greater ozonation efficiency, and catalytic ozonation is found to be more effective for the removal of several pollutants from aqueous solution. ${ }^{17}$

Among AOPs, heterogeneous catalytic ozonation has received much attention in water treatment ${ }^{18}$ due to its high oxidizing potential,,${ }^{19}$ and the improvement in their performance when using metal oxides, or metals on metal oxide supports (e.g. $\mathrm{MnO}_{2}, \mathrm{TiO}_{2}, \mathrm{Al}_{2} \mathrm{O}_{3} \mathrm{Cu}-\mathrm{Al}_{2} \mathrm{O}_{3}, \mathrm{Cu}-\mathrm{TiO}_{2}, \mathrm{Ru}-\mathrm{CeO}_{2}, \mathrm{~V}-\mathrm{O} /$ $\mathrm{TiO}_{2}, \mathrm{~V}-\mathrm{O} /$ silica gel and $\left.\mathrm{TiO}_{2} / \mathrm{Al}_{2} \mathrm{O}_{3}, \mathrm{Fe}_{2} \mathrm{O}_{3} / \mathrm{Al}_{2} \mathrm{O}_{3}\right)^{3} .{ }^{20,21,22,23}$

During degradation of organic pollutants, the removal of recalcitrant compounds generated is difficult. Our group reported the removal of recalcitrant compounds such as oxalic acid in aqueous solutions using a catalytic ozonation process with $\mathrm{MnO}_{2} / \mathrm{TiO}_{2}{ }^{24}$ However, these studies should be supported with toxicity studies.

In the present work, we present the study of degradation process PCP by ozonation in a batch reactor using $\mathrm{MnO}_{2} / \mathrm{TiO}_{2}$ as a catalyst. The effect of the $\mathrm{pH}$ solution, the relationship between the disappearance rate of the model compound, the generation of intermediates, and the toxicity of the medium during the reaction were also studied. The intermediates of these processes were identified by chromatographic techniques and their toxicity on biological systems was evaluated using in vivo tests on Daphnia magna, Lactuca sativa and Panicum millaceum.

\section{MATERIAL AND METHODS}

\subsection{Reagents and chemicals}

Pentachlorophenol $86 \%$ p.a. (Aldrich) was used without further purification, hydrogen peroxide reagent grade $30 \%$ (Merck), analytical grade reagents or calibration standard supplied by Merck or Mallinckrodt were used for HPLC measurements. All solutions used in the degradation studies were prepared using double distilled water. The catalyst was prepared using a commercial $\mathrm{TiO}_{2}$ Degussa $\mathrm{P} 25$ and $\mathrm{Mn}\left(\mathrm{NO}_{3}\right)_{2} \cdot 4 \mathrm{H}_{2} \mathrm{O}$ (Merck).

\subsection{Catalyst}

Catalyst $\mathrm{MnO}_{2} / \mathrm{TiO}_{2}$ was prepared using $\mathrm{TiO}_{2}$ Degussa $\mathrm{P} 25$ as support with $1 \% \mathrm{w} / \mathrm{w} \mathrm{MnO}_{2}$, by impregnation at $35^{\circ} \mathrm{C}$ with an aqueous $\mathrm{Mn}\left(\mathrm{NO}_{3}\right)_{2}$ solution using the incipient wetness method. The solid was dried at $120^{\circ} \mathrm{C}$ for $12 \mathrm{~h}$ and calcined in air at $500^{\circ} \mathrm{C}$ for $4 \mathrm{~h} \cdot{ }^{25}$ (Villaseñor, 2002). Its characterization was by evaluated specific surface area and porosity in an automatic Gemini 2370 Micromeritics system, from the $\mathrm{N}_{2}$ adsorption isotherm at $-196^{\circ} \mathrm{C}$ in the relative pressure range of $0.05-0.995$. X-ray analysis for the catalyst was made on a Bruker D8 Advance instrument with Linear LynxEye detector, BraggBrentane geometry, $\mathrm{Cu} \lambda=1.5406 \mathrm{~A}, 40 \mathrm{KV}-30 \mathrm{~mA}$ power, and $0.1 \mathrm{~mm}$ fixed optics. Temperature Program Reduction (TPR) experiments were carried out 
in a TPR/TPD (Temperature Program Desorption) 2900 Micromeritics system provided with a thermal conductivity detector. The reducing gas was a mixture of $5 \% \mathrm{H}_{2} / \mathrm{Ar}\left(40 \mathrm{~cm}^{3} / \mathrm{min}\right)$ and a heating rate of $10 \mathrm{~K} / \mathrm{min}$ was used. The TPD of ammonia was carried out using an Ar flow of $50 \mathrm{~cm}^{3} / \mathrm{min}$ as carrier gas. Ammonia pulses were dosed in order to saturate the catalyst surface at $100^{\circ} \mathrm{C}$; the sample was cooled to room temperature, and once the base line was restored the temperature was increased linearly $(10 \mathrm{~K} / \mathrm{min})$ up to $500^{\circ} \mathrm{C} .{ }^{24}$ The zero point charge (zpc) was obtained by measuring the zeta-potentials as a function of $\mathrm{pH}$ suspensions. ${ }^{26}$ The measurements were carried out in a Zeta-Meter Inc. (Model ZM-77) using $20 \mathrm{mg}$ of $2 \mu \mathrm{m}$ catalyst particles ultrasonically suspended in 200 $\mathrm{mL}$ of $1 \times 10^{-3} \mathrm{~mol} / \mathrm{L} \mathrm{KCl}$ solution.

\subsection{Degradation experiments}

The following processes were studied: UV processes ( $U V$ and $\mathrm{UV} / \mathrm{H}_{2} \mathrm{O}_{2}$ ), ozonation processes $\left(\mathrm{O}_{3}, \mathrm{O} / \mathrm{H}_{2} \mathrm{O}, \mathrm{O} / \mathrm{UV}\right)$, and catalytic ozonation. The degradation process was performed in a Pyrex glass reactor. ${ }^{27}$ It was charged with $90 \mathrm{~mL}$ of aqueous solution of PCP with an initial concentration of 30 $\mathrm{mg} / \mathrm{L}$. The $\mathrm{MnO} / \mathrm{TiO}_{2}$ catalyst $(2.2 \mathrm{~g} / \mathrm{L})$ was kept in suspension with magnetic stirring. The external chamber of the reactor was kept at $20^{\circ} \mathrm{C}$ or $40^{\circ} \mathrm{C}$ by recirculation of water. For the ozonation processes, the ozone was generated by an OZOCAV ozonizer ${ }^{25}$ and fed at an oxygen flow of $50 \mathrm{~mL} / \mathrm{min}$, reaching an ozone concentration of $22.11 \mathrm{mg} / \mathrm{L}$. The $\mathrm{H}_{2} \mathrm{O}_{2}$ was used at $1.5 \times 10^{-4} \mathrm{~mol} / \mathrm{L}$ for each reaction.

For the experiments performed under UV light, the solution were irradiated with a General Electric UV lamp (HR 250 DX 37/40, $\lambda \geq 254 \mathrm{~nm}$ ) across the quartz reactor windows. The lamp was placed at the top of the window $5 \mathrm{~cm}$ over the sample. ${ }^{27}$ The reactions were ran at $\mathrm{pH} 5,7$ and 9 .

\subsection{Analytical methods}

Prior to the analysis, the samples were extracted from the reactor at several reaction times (0-60 min) and filtered through 0.20 $\mu \mathrm{m}$ membrane (Millipore). The concentrations of PCP and its degradation intermediates were measured with an HPLC system coupled to a Perkin Elmer Series 200 chromatograph with a UV-VIS detector. All the intermediates were identified by HPLC by comparing the retention time of the standard solution and comparing the GCMS with the mass spectra of the intermediate compound in the database of NIST (National Institute of Standards and Technology). The following conditions were used for aromatic compounds; a Merck-Chromolith Performance RP-18 column $(4.6 \mathrm{~mm} \times 100 \mathrm{~mm})$. The mobile phase was an acetonitrile: $\mathrm{H}_{3} \mathrm{PO}_{4}\left(7 \times 10^{-}\right.$ ${ }^{3} \mathrm{~mol} / \mathrm{L}$ ) mixture $(40: 60)$, with a flow rate of $1.5 \mathrm{~mL} / \mathrm{min}$, and a wavelength detection at $215 \mathrm{~nm}$. The analyses of the acid compounds were made with a Transgenomic ORH-801 column $(6.5 \mathrm{~mm} \times 300 \mathrm{~mm})$ with $5 \times 10^{-3} \mathrm{~mol} / \mathrm{L}$ sulfuric acid as eluent $(0.8 \mathrm{~mL} / \mathrm{min})$ at $200 \mathrm{~nm}$.

Evolution of $\mathrm{CO}_{2}$ was monitored according to previously described method. ${ }^{27}$ Chloride samples were quantified by a potentiometric method ${ }^{29}$ using an ORION specific chloride electrode.

\subsection{Ecotoxicity assay}

The ecotoxicity assays were performed using Daphnia magna (microcrustacean) and two plant species, Lactuca sativa (lettuce) and Panicum millaceum (millet), as dicotyledon and monocotyledon representatives, respectively. ${ }^{28,29,30}$

Several colonies of D. magna were maintained at $20^{\circ} \mathrm{C}$. All the tests were performed in the dark at constant temperature of $20 \pm 2^{\circ} \mathrm{C}$. Acute toxicity was assessed by recording the effects of the compounds tested on the motility of D. magna. Daphnids less than $24 \mathrm{~h}$ old were used for the assays. The effective media concentration $\left(\mathrm{EC}_{50}\right)$ was determined as the concentration estimated to immobilize $50 \%$ of the daphnids after $24 \mathrm{~h}$ and $48 \mathrm{~h}$ of exposure with the $30 \mathrm{mg} / \mathrm{L}$ PCP solutions; the data was analyzed with Probit model statistical method. ${ }^{31,32}$ The toxicity of the samples was reported as percent of immobilized daphnides with respect to a control (water). To compare the effects with the initial PCP concentration, the tests were performed using a same sample volume, higher than $\mathrm{EC}_{50}$ of PCP $(0.75 \mathrm{mg} / \mathrm{L}$ at 48 hours $)$. In all the experiments, a $300 \mu \mathrm{L}$ of degradation process samples and PCP solution $(30 \mathrm{mg} / \mathrm{L})$ was completed to 10 $\mathrm{mL}$ with water.

Lettuce (Lactuca sativa) and millet (Panicum millaceum) seeds were selected as phytotoxicity bioindicators because they germinate very quickly and sprouts show rapid growth. Ten seed per plants were placed on a filter paper inside a vial and $200 \mu \mathrm{L}$ of undiluted degradation samples were added. After a period, growth 3 days of light and 3 days of darkness at $25^{\circ} \mathrm{C}$, stems and roots length were recorded and expressed as the percentage length with respect of control plants treated with water. The statistical significance of differences between groups was determined by one-way ANOVA ( $p$-value $\leq 0.05)$ and compared with the control group by the Dunnett-test. ${ }^{28,29,30}$

\section{RESULTS AND DISCUSSION}

\subsection{Uncatalyzed Reactions}

PCP degradation at a concentration of $30 \mathrm{mg} / \mathrm{L}$ was studied across the time in the absence of the catalyst. The $\mathrm{pH}$ of the solution was adjusted to $\mathrm{pH} 5, \mathrm{pH}$ 7 and $\mathrm{pH} 9$ with a phosphate buffer, and the process was monitored at $20^{\circ} \mathrm{C}$ and $40^{\circ} \mathrm{C}$. Assuming pseudo-first-order kinetics, the rate constant was between $0.4-0.5 \pm 0.1 \mathrm{~min}^{-1}$ in the presence only of ozone at $20^{\circ} \mathrm{C}$ in all $\mathrm{pH}$ tested; at $40^{\circ} \mathrm{C}$, a slight increase in the rate constant of $0.7 \pm 0.1 \mathrm{~min}^{-1}$ was achieved. At 10 minutes of uncatalyzed ozonation reaction, $96 \pm 2 \%$ degradation of PCP at both temperatures was reached.

The Fig. 1 shows the degradation of $\mathrm{PCP}$ to $\mathrm{pH} 7$ at $20^{\circ} \mathrm{C}$ in the presence of $\mathrm{O}_{3}, \mathrm{O}_{3} / \mathrm{UV} / \mathrm{H}_{2} \mathrm{O}_{2}$ and $\mathrm{UV} / \mathrm{H}_{2} \mathrm{O}_{2}$. In order to optimize the reaction system, $\mathrm{UV}, \mathrm{H}_{2} \mathrm{O}_{2}$ and combinations of both were included; remarkably, in the absence of ozone a slow degradation of PCP was observed, with rate constants between $2 \times 10^{-3}-6 \times 10^{-3} \mathrm{~min}^{-1}$. On the other hand, no significant impact on PCP decomposition at both temperatures was observed under these conditions. The purpose of introducing UV radiation in the ozonation processes was to yield more free radicals for the higher ozonation rate, as was found in the decomposition of polyethylene glycol by $\mathrm{O}_{3}$ with UV radiation. ${ }^{33}$ These small differences found in the rate reaction for PCP degradation with the addition of $\mathrm{H}_{2} \mathrm{O}_{2}$ or $\mathrm{UV}$ irradiation, indicate that $\mathrm{O}_{3}$ is the main agent involved in the process.

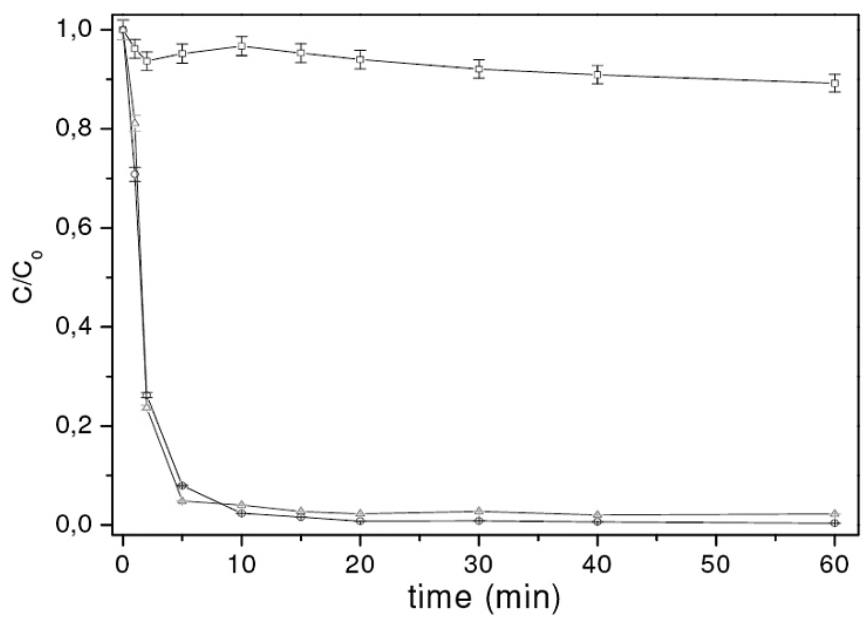

Figure 1: Degradation of PCP at $\mathrm{pH} 7$ during 60 minutes in the presence of $\mathrm{O}_{3}(\Delta), \mathrm{O}_{3} / \mathrm{UV} / \mathrm{H}_{2} \mathrm{O}_{2}(\mathrm{O})$ and $\mathrm{UV} / \mathrm{H}_{2} \mathrm{O}_{2}(\square)$.

In this study, chloride and $\mathrm{CO}_{2}$ were found as mineralization products. The release of $\mathrm{Cl}^{-}$after $60 \mathrm{~min}$ of ozonation was $4.2 \times 10^{-4} \mathrm{~mol} / \mathrm{L}$ at $\mathrm{pH} 9$ and $2.2 \times 10^{-}$ ${ }^{4} \mathrm{~mol} / \mathrm{L}$ at $\mathrm{pH} 5$. However, without $\mathrm{O}_{3}$, the chloride production was lower. The formation of $\mathrm{CO}_{2}$ was $\sim 1.1 \times 10^{-5} \mathrm{~mol} / \mathrm{L}$ with $\mathrm{O}_{3}$ and $\sim 4 \times 10^{-6} \mathrm{~mol} / \mathrm{L}$ in the absence of ozone. The ozonation process led to an increased mineralization effect compared to the photochemical processes and oxidation by peroxide. The importance of $\mathrm{O}_{3}$ in the PCP degradation is evident according to the reactions in the experiments, Fig. 1.

In water, ozone can oxidize contaminants by direct selective reactions, resulting in the addition to $\mathrm{C}=\mathrm{C}$ bonds to or through a chain reaction mechanism that produces free hydroxyl radicals, which are stronger oxidants than molecular ozone. ${ }^{34}$ The production of hydroxyl radicals by ozone in aqueous solution may be taken placed through chain reactions as shown in equations $1-4,{ }^{19}$ or by traces of other substances, such as transition metal cations, that leads to an indirect attack on organic compounds, which is faster than a direct attack by molecular ozone. ${ }^{24}$

$$
\begin{aligned}
& \mathrm{O}_{3}+\mathrm{H}_{2} \mathrm{O} \rightarrow 2 \mathrm{HO}^{\bullet}+\mathrm{O}_{2} \\
& \mathrm{O}_{3}+\mathrm{OH}^{-} \rightarrow \mathrm{O}_{2}^{\bullet}+\mathrm{HO}_{2}^{\bullet} \\
& \mathrm{O}_{3}+\mathrm{HO}^{\bullet} \rightarrow \mathrm{O}_{2}+\mathrm{HO}_{2}^{\bullet} \\
& \mathrm{O}_{3}+\mathrm{HO}_{2}^{\bullet} \leftrightarrow 2 \mathrm{O}_{2}+\mathrm{HO}^{\bullet}
\end{aligned}
$$


During the uncatalyzed ozonation process of PCP, intermediates formation, namely tetrachloro-1,2-hydroquinone (TCl-1,2-HQ) and tetrachloro-1,2-benzoquinone (TCl-1,2-BQ), at $\mathrm{pH} 5$ and tetrachloro-1,4hydroquinone (TCl-1,4-HQ) and tetrachloro-1,2-hydroquinone (TCl-1,4-BQ) at $\mathrm{pH}$ 9, were identified (Fig. 2). The major intermediate identified in the first minutes of uncatalyzed ozonation was TCl-1,2-HQ at $\mathrm{pH} 5$, which may be produced as a result of the attack of either ozone or a hydroxyl radical on the carbon in ortho position of the PCP molecule. TCl-1,2-BQ is the oxidation product of TCl-1,2-HQ, which produces a reddish solution. At the same time, dehalogenation products such as phenols and mono-, di- and/or tri- chlorophenols were formed. It is likely that these later compounds are products of electron transfer reactions between the hydroxyl radical and PCP, which generate in the first instance cation radicals such as those shown in Schemes 1 and 2, as proposed previously by Legrini and co-workers. ${ }^{35}$ These radicals may then react to produce the corresponding dehalogenation products. Moreover, the insertion of a hydroxyl group generates dehalogenation products, resorcinol and hydroquinone, as shown in the scheme 2. First, the dehalogenation of PCP produces tetrachlorocatechol, which also undergoes dehalogenation and addition of hydroxyl groups affording pyrogalol and catechol.

\section{$\mathrm{HO}^{\bullet}+\mathrm{RX} \longrightarrow \mathrm{RX}^{\cdot+}+\mathrm{OH}^{-}$ \\ Sheme 1}

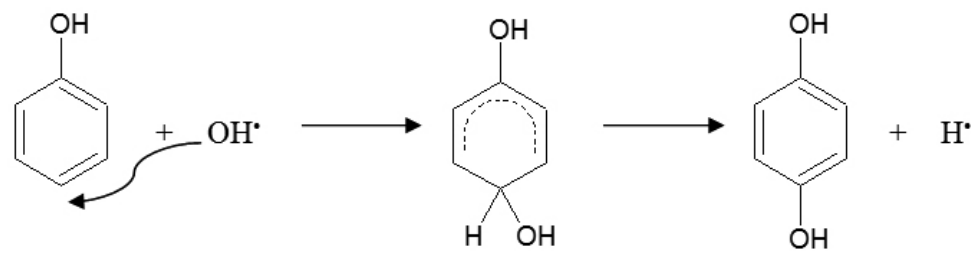

Sheme 2

The subsequent oxidation of these compounds causes the breaking of the benzene ring and the formation of low molecular weight carboxylic acids such as maleic, oxalic, trichloroacetic and formic acids. The formation of trichloroacetic acid can be explained by the proposal made by Anipsitakis and co-workers $^{37}$ from 1,1,3,3-tetrachloroacetone (scheme 3):

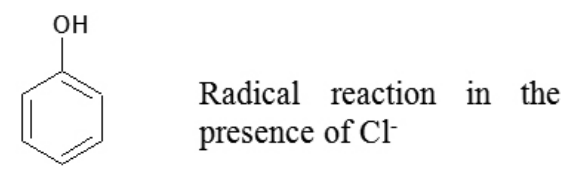

(Scheme 3)

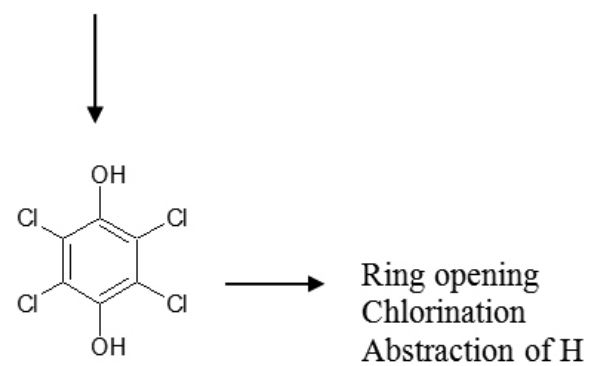<smiles>CCCCCC(=O)C(Cl)Cl</smiles><smiles>O=C(O)C(Cl)(Cl)Cl</smiles>

trichloroacetic acid

$1,1,3,3-$

tetrachloroacetone

Sheme 3

In addition to the formation of several quinones, the final steps in this oxidation process was the conversion of these carboxylic acids to complete mineralization products, carbon dioxide, chloride, and water.

It is noteworthy that TCl-1,2-BQ at $\mathrm{pH} 5$ and 1,4-BQ at $\mathrm{pH} 9$, were respectively formed as the main PCP degradation intermediates (Fig. 3 and 4). According to the $\mathrm{pK}_{\mathrm{a}}$ of $\mathrm{PCP}$, at $\mathrm{pH} 5$ the phenolate ion reaches $67 \%$, while at $\mathrm{pH} 9$ it is $99.9 \%$ of the phenolate ion. The negative charge on the oxygen atom can hinder the attack of hydroxyl in an ortho position, favoring the addition in para position at $\mathrm{pH}$ 9. Under alkaline conditions, a greater degree of dehalogenation products like phenol, pyrogalol or resorcinol at higher concentrations than under acidic conditions was observed. The products of oxidation of these compounds at both experimental $\mathrm{pH}$ conditions included the formation of maleic, oxalic and formic acids, however at $\mathrm{pH} 9$ there was generation of additional organic acids such as tartaric and malonic. For the mineralization products, chloride evolution was greater at basic $\mathrm{pH}$ than under acidic conditions. The percentage of dechlorination at $60 \mathrm{~min}$ of reaction reached $75 \%$ of the theorical value.

According to these results, we propose degradation pathways (Fig. 3 and 4) with the main intermediaries detected during the uncatalyzed ozonation process of $\mathrm{PCP}$ at $\mathrm{pH} 5$ and $\mathrm{pH} 9$. 

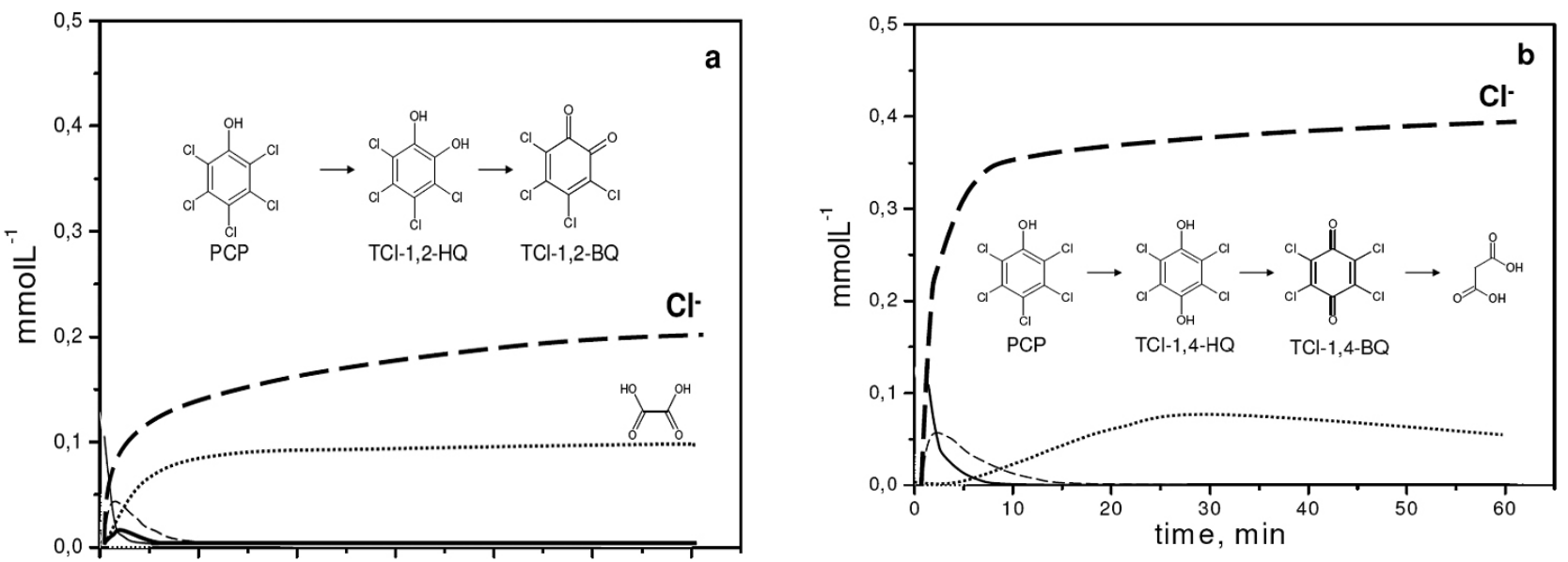

Figure 2: Degradation of PCP (-) at (a) $\mathrm{pH} 5$ and (b) $\mathrm{pH} 9$ with the evolution of $\mathrm{Cl}^{-}(----)$and the presence of the main products of degradation found under these conditions (TCl-HQ ---- and TCl-BQ ……..).<smiles>Oc1c(Cl)c(Cl)c(Cl)c(Cl)c1Cl</smiles>

pentachlorophenol

$(33 \%)$

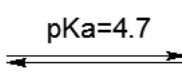<smiles>[O-]c1c(Cl)c(Cl)c(Cl)c(Cl)c1Cl</smiles>

pentachlorophenolate $(67 \%)$
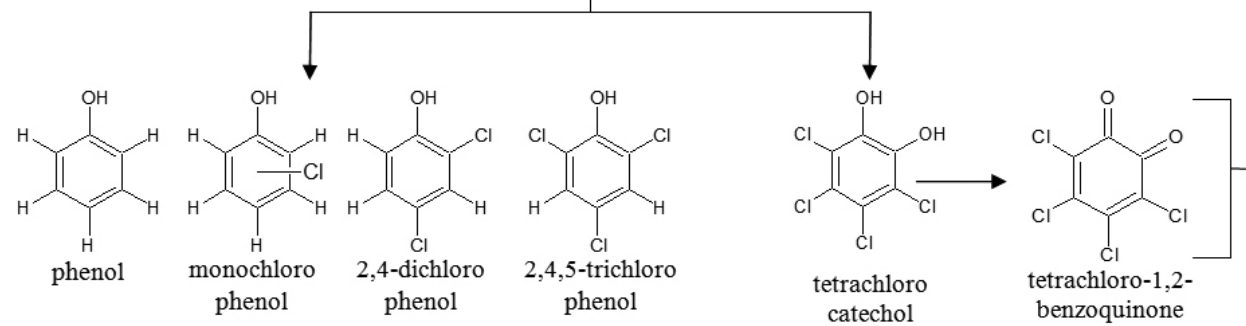
catechol (red)<smiles>Oc1ccccc1</smiles><smiles>Oc1ccccc1</smiles><smiles>Oc1ccccc1</smiles>

phenol hydroquinone<smiles>Oc1ccccc1</smiles>

pyrogallol<smiles>Oc1ccccc1</smiles>

catechol

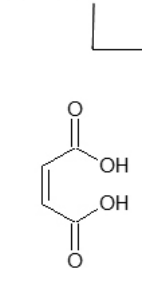

maleic acid

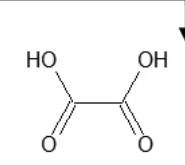

oxalic acid<smiles>O=CO</smiles>

formic acid<smiles>O=C(O)C(F)(Cl)Cl</smiles>

trichloroacetic acid

$$
\mathrm{CO}_{2}+\mathrm{H}_{2} \mathrm{O}+\mathrm{Cl}^{-}
$$

Figure 3: Degradation pathway proposal with the main intermediaries detected during the ozonation process of PCP at $\mathrm{pH} 5$. 
<smiles>Oc1c(Cl)c(Cl)c(Cl)c(Cl)c1Cl</smiles>

pentachlorophenol<smiles>Oc1ccccc1</smiles><smiles>Oc1ccccc1</smiles><smiles>Oc1ccccc1Cl</smiles>

2,4-

phenol

monochloro dichlorophenol phenol

\section{$\mathrm{pKa}=4.7$}

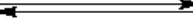

pentachlorophenolate<smiles>Oc1ccccc1</smiles>

Phenol

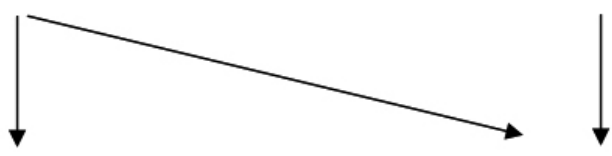<smiles>Oc1c(Cl)c(Cl)c(Cl)c(Cl)c1Cl</smiles>

tetrachloro catechol
(99.9\%)<smiles>[O-]c1c(Cl)c(Cl)c(Cl)c(Cl)c1Cl</smiles><smiles>O=C(O)/C=C\C(=O)O</smiles>

maleic acid<smiles>Oc1ccccc1</smiles>

pyrogallol<smiles>Oc1ccccc1</smiles>

resorcinol<smiles>Oc1c(Cl)c(Cl)c(O)c(Cl)c1Cl</smiles>

tetrachloro hydroquinone<smiles>C=C</smiles>

$$
\checkmark
$$

hydroquinone<smiles>CCC(=O)C(O)C(O)C(=O)O</smiles>

tartaric acid<smiles>O=C(O)CC(=O)O</smiles>

malonic acid<smiles>O=C(O)C(=O)O</smiles>

oxalic acid<smiles>O=CO</smiles>

formic acid<smiles>CCC1CCCCC1Cl</smiles>

tetrachloro-1,4benzoquinone (yellow)
$\mathrm{CO}_{2}$
$+$
$\mathrm{H}_{2} \mathrm{O}$
$+$
$\mathrm{Cl}^{-}$

Figure 4: Degradation pathway proposal with the main intermediaries detected during the ozonation process of $\mathrm{PCP}$ at $\mathrm{pH} 9$

\subsection{Catalyst Characterization}

The preparation of the catalyst $\mathrm{MnO}_{2} / \mathrm{TiO}_{2}$ was reported previously. ${ }^{25}$ Table 1 summarizes the characterization of the catalysts studied. Some of these results have been previously reported by our group ${ }^{24}$.

The textural properties of the catalyst $\mathrm{MnO}_{2} / \mathrm{TiO}_{2} 1 \%$ were evaluated by nitrogen sorption experiments. The specific surface area and average pore radius obtained from nitrogen adsorption were $43 \mathrm{~m}^{2} / \mathrm{g}$ and $5.0 \mathrm{~nm}$, respectively. The specific surface area of the solids obtained from nitrogen adsorption isotherms at $77 \mathrm{~K}$ showed the expected trends. The addition of manganese oxide to the support produces a slight decrease in the surface due to surface coverage.

Surface acidity obtained from the TPD of ammonia showed a single, wide peak centered at $533 \mathrm{~K}$ for $\mathrm{TiO}_{2} . \mathrm{MnO}_{2} / \mathrm{TiO}_{2}$ catalyst showed two peaks, the first one was broad and centred at $533 \mathrm{~K}$ while the second presented a higher intensity centred at $790 \mathrm{~K}$. Table 1 presents surface acidity estimated from TPD data. The $\mathrm{MnO}_{2} / \mathrm{TiO}_{2}$ catalyst displays the highest value. If it is considered that the bulk $\mathrm{MnO}_{2}$ possess a surface acidity of 0.095 meq g $\mathrm{g}^{-1}$ and the $\mathrm{MnO}$ loading is only $1 \mathrm{wt} \%$, only a slight increase should be expected. However, the obtained surface acidity of $\mathrm{MnO}_{2} / \mathrm{TiO}_{2}$ is approximately $50 \%$ higher than the pure support, which is indicative of $\mathrm{MnO}_{2}^{2}$ 's high surface coverage.

The ZPC values are also displayed in Table 1. Taking into account that the bulk $\mathrm{TiO}_{2}$ displays a $\mathrm{ZPC}$ of 6.1 , a decrease in $0.5 \mathrm{pH}$ units after the deposition of $\mathrm{MnO}_{2}$ on $\mathrm{TiO}_{2}$ is observed. Since the $\mathrm{ZPC}$ of bulk $\mathrm{MnO}_{2}$ is 3.4, an estimate of surface coverage indicates that approximately $20 \%$ of the $\mathrm{TiO}_{2}$ surface is coverage with $1 \mathrm{wt} \%$ of $\mathrm{MnO}_{2}$, indicating a high dispersion of the oxide phase. 
Table 1. Surface area, surface acidity and $\mathrm{ZPC}$ for $\mathrm{TiO}_{2}$ and $\mathrm{TiO}_{2} / \mathrm{MnO}_{2}$ catalysts.

\begin{tabular}{|c|c|c|c|}
\hline Catalyst & $\begin{array}{c}\mathrm{S}_{\mathrm{BET}}, \\
\mathrm{m}^{2} \mathrm{~g}^{-1}\end{array}$ & $\begin{array}{c}\text { Surface acidity, } \\
\text { meq } \mathrm{g}^{-1}\end{array}$ & $\begin{array}{c}\mathrm{ZPC}, \\
\mathrm{pH} \text { units }\end{array}$ \\
\hline $\mathrm{TiO}_{2}$ & 49 & 0.024 & 6.1 \\
\hline $\mathrm{MnO}_{2} / \mathrm{TiO}_{2}$ & 43 & 0.037 & 5.6 \\
\hline
\end{tabular}

The Fig. 5 shows the XRD (X-Ray Diffraction) of $\mathrm{MnO}_{2} / \mathrm{TiO}_{2} 1 \% \mathrm{w} / \mathrm{w}$. The catalyst has anatase (PDF file 00-021-1272) and rutile (PDF file 00-0211276) phases, characteristic of titanium oxide; the manganese oxide phase was not be detected, probably due to the low amount of this oxide in the catalyst.

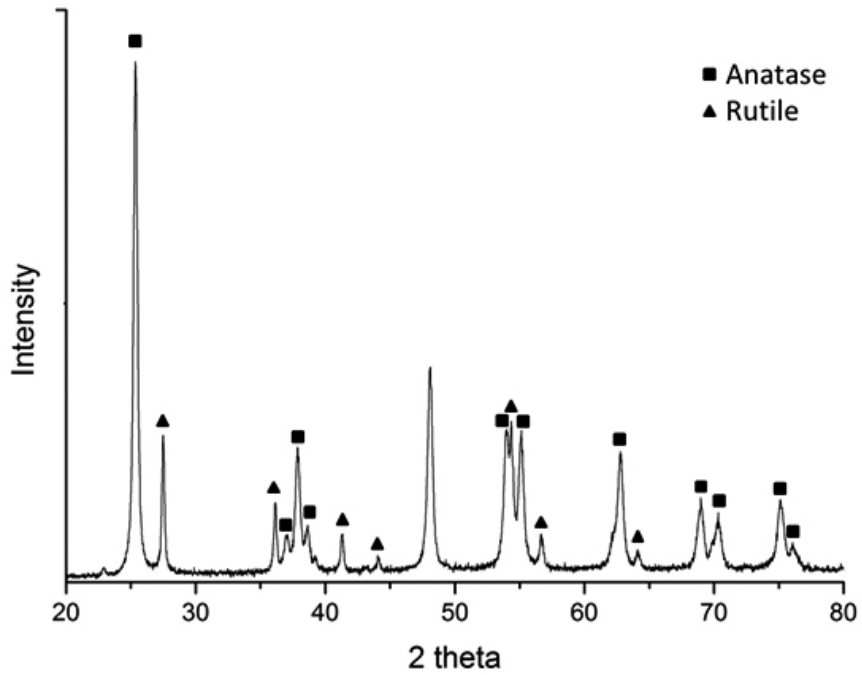

Figure 5: $\mathrm{XRD}$ of $\mathrm{MnO}_{2} / \mathrm{TiO}_{2}$ catalyst.

\subsection{Catalytic Ozonation}

The catalytic ozonation reactions of PCP were studied at $20^{\circ} \mathrm{C}$ and at different $\mathrm{pH}$. At $\mathrm{pH} 5$ the rate constant was $0.7 \pm 0.1 \mathrm{~min}^{-1}$, whereas at $\mathrm{pH} 7$ and 9 the $\mathrm{k}$ was $0.4 \pm 0.1 \mathrm{~min}^{-1}$. The slightly higher value of the rate constant at $\mathrm{pH} 5$ can be explained by a major adsorption of phenolate anions on the slightly positive catalyst surface $(\mathrm{ZPC}=5.6)$, allowing a better contact between PCP and oxidant species on the surface of the catalyst. ${ }^{37}$. Nevertheless, adsorption of PCP in the dark is rather small along all the $\mathrm{pH}$ values employed. The average amount of PCP adsorbed on $\mathrm{TiO}_{2}$ was $3.7 \%$ and $4.7 \%$ for $\mathrm{TiO}_{2} / \mathrm{MnO}_{2}$.

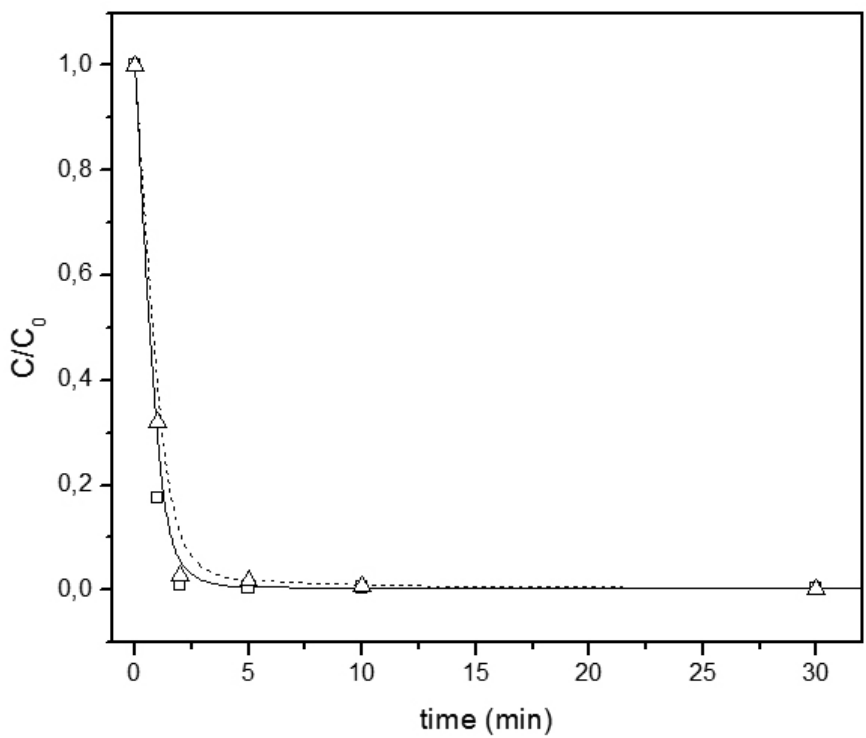

Figure 6: Degradation of $\mathrm{PCP}$ at $\mathrm{pH} 5$ during 30 minutes with $\mathrm{TiO} / \mathrm{MnO}_{2}$ $(\square)$ and without $\mathrm{TiO}_{2} / \mathrm{MnO}_{2}(\Delta)$
Fig. 6 shows the diminution of PCP concentration over time during the first 30 minutes of reaction at $\mathrm{pH} 5$. Under the experimental conditions employed in this work degradation of PCP is relatively fast, and just a slight difference can be observed.

Although the nature of the intermediates found is the same than in the case of homogeneous ozonation, the effect of the use of $\mathrm{TiO}_{2} / \mathrm{MnO}_{2}$ is expressed in the change of the proportions of these intermediates. Differences were observed in chloride and $\mathrm{CO}_{2}$ evolution, which were higher than in a catalyzed presence, indicating a different route to mineralization. Theoretically if the PCP is completely degraded, it would generate $5.6 \times 10^{-4} \mathrm{~mol} / \mathrm{L}$ of chlorides, when comparing the production of chlorides at different $\mathrm{pH}$, it is observed that the highest amount of chlorides formed is at $\mathrm{pH} 9$ producing $5.0 \times 10^{-5} \mathrm{~mol} / \mathrm{L}$ at the end of the reaction. The greatest degradation of PCP occurs in the first few minutes of the reaction, where the highest $\mathrm{CO}_{2}$ formation is observed. During ozonation reactions at $\mathrm{pH} 5$ and $\mathrm{pH} 9, \mathrm{CO}_{2}$ was generated reaching concentrations of $7 \times 10^{-6} \mathrm{~mol} / \mathrm{L}$ and $2.8 \times 10^{-6} \mathrm{~mol} / \mathrm{L}$ respectively, while in the catalytic ozonation reactions, an increase in the $\mathrm{CO}_{2}$ generation was observed at both $\mathrm{pH}$ values, reaching $9.5 \times 10^{-6} \mathrm{~mol} / \mathrm{L}$ at $\mathrm{pH} 5$, and $6 \times 10^{-6} \mathrm{~mol} / \mathrm{L}$ at $\mathrm{pH} 9$ after 40 min of degradation.

\subsection{Toxicity assays}

One of the objectives of this study was to verify that products generated in the process of degradation of PCP do not show more toxicity than the initial compound. Using Daphnia magna as a representative species of an aquatic organism (Ecotoxicity assay) and Lactuca sativa and Panicum millaceum as terrestrial organism (Phytoxicity assay)

According to several reports, many catalytic processes can generate products that are more toxic than the initial substances. ${ }^{38,39,40}$ It was expected that the lower formation of halogenated intermediates would produce less toxic solutions.$^{41}$ Our results indicate that the lowest formation of organohalide compounds is performed at $\mathrm{pH} 9$, therefore this system was selected for the following ecotoxicity tests.

\subsection{Ecotoxicity assay}

The microcrustacean Daphnia magna was used according to Chilean Standards. The first assay consisted in evaluating the initial solution of PCP $(30 \mathrm{mg} / \mathrm{L})$ at different $\mathrm{pH}$ values, because PCP degradation process was dependent on the $\mathrm{pH}$. The results are presented in Table 3. It was determined the $\mathrm{IC}_{50}$ for PCP with average values of $0.8 \mathrm{mg} / \mathrm{L}$ and $0.6 \mathrm{mg} / \mathrm{L}$, at $24 \mathrm{~h}$ and $48 \mathrm{~h}$, respectively. An ecotoxicity positive control, $\mathrm{IC}_{50}$ for $\mathrm{K}_{2} \mathrm{Cr}_{2} \mathrm{O}_{7}(1.2 \pm$ $0.07 \mathrm{mg} / \mathrm{L}$ ) was included in the assay. These results are reasonably consistent with that previously reported for PCP $\left(\mathrm{IC}_{50-24 \mathrm{~h}}=0.62 \mathrm{mg} / \mathrm{L}\right)$ using the same microcrustaceans. ${ }^{42}$

Table 3: Results of ecotoxicity with Daphnia magna for the model compound PCP.

\begin{tabular}{|c|c|c|}
\hline$p H$ & $I C_{50-24 h}$ & $I C_{50-48 h}$ \\
\hline $\mathrm{pH} \mathrm{5}$ & $0.7 \mathrm{mg} / \mathrm{L}$ & $0.6 \mathrm{mg} / \mathrm{L}$ \\
\hline $\mathrm{pH} 7$ & $0.9 \mathrm{mg} / \mathrm{L}$ & $0.6 \mathrm{mg} / \mathrm{L}$ \\
\hline $\mathrm{pH} 9$ & $0.8 \mathrm{mg} / \mathrm{L}$ & $0.6 \mathrm{mg} / \mathrm{L}$ \\
\hline
\end{tabular}

To study the evolution of toxicity during the ozonation reaction, samples from uncatalyzed and catalytic ozonation were taken at different reaction times and diluted to reach approximately twice the $\mathrm{IC}_{5048 .}$. At time zero, when the degradation process had not started, the survival percentage was zero. The percentage of survival increased rapidly when the microcrustacean were incubated with both ozonation samples obtained from 15 minutes of reaction and beyond (data not shown). The decrease in toxicity must be related to the decrease in concentration of PCP and the formation of less toxic intermediates formed during the ozonation process. No significant differences were found in the survival profile between the $\mathrm{MnO}_{2}$ catalyzed ozonation regarding the uncatalyzed process (data not shown).

\subsection{Phytotoxicity assay}

Phytotoxicity tests were performed using seeds of Lactuca sativa (dicotyledonous) and Panicum millaceum (monodicotyledonous). In two tests, the growth of root and stem of both species were measured after 6 days of incubation. The seeds were treated with samples obtained during the degradation of PCP, and distilled water was used as a control. In the case of lettuce assays, it was not observed any significant differences in presence and absence of catalyst. 
The Fig. 7, shows the growth percentage of root and stem of Panicum millaceum exposed to PCP solutions sampled at different time intervals during ozonation and catalytic ozonation at $\mathrm{pH} 9$. An initial solution of $30 \mathrm{mg} / \mathrm{L} \mathrm{PCP}$ (time $0 \mathrm{~min}$ ) inhibited the root growth $\sim 65 \%$ and stem growth $\sim 50 \%$.

It is observed that stem and root growth is favored when the $\mathrm{MnO}_{2} / \mathrm{TiO}_{2}$ catalyst is used in the degradation process of PCP.
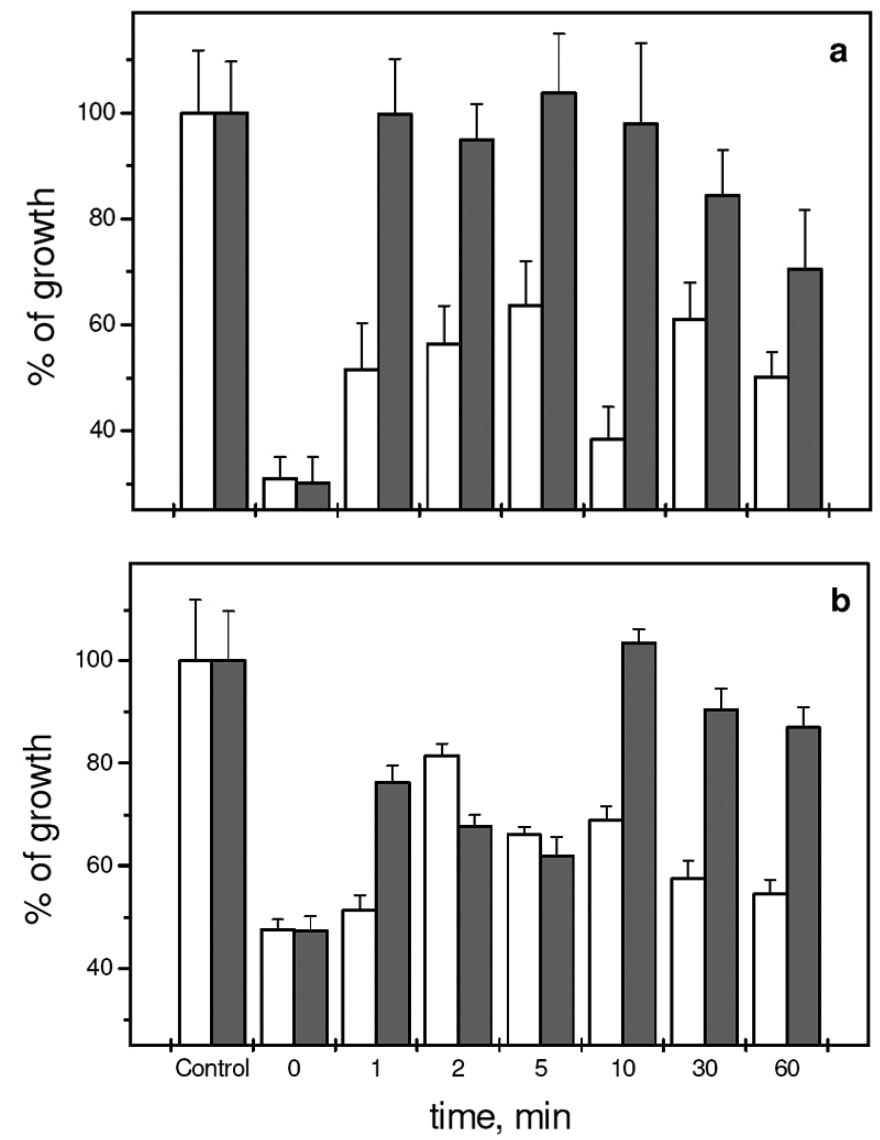

Figure 7. Effect of samples taken at different time intervals during the PCP treatment for ozonation in the presence of $\left(\mathrm{MnO}_{2} / \mathrm{TiO}_{2}\right) \square$ to $\mathrm{pH} 9$ and in the absence of catalyst, $\square$ expressed as percentage of root growth (a) and stem growth (b) of germinated seeds of Panicum millaceum, compared with a control (water). $(p<0.05)$.

Fig. 7a shows that the root initially grows around 30\% observing an increase in growth as the degradation of PCP occurs. In addition, it is observed that when using the catalyst, the growth of the root is very noticeable. This behavior could be explained by the generation of intermediaries in different proportion, Fig. 7b where stem growth is observed, also shows that the use of the catalyst helps in the reduction of toxicity, reflected in a greater growth of the stem, observing its greater effect after 10 min of degradation, reaching up to $90 \%$ stem growth.

\section{CONCLUSION}

The ozonation is a dominant process during the degradation of PCP, which achieved $\sim 95 \%$ of PCP degradation at $60 \mathrm{~min}$ of reaction. It was observed that during the degradation of PCP, quinones were generated as main intermediates that quickly decay leading the formation of several organic acids as degradation products.

The degradation of PCP by ozone was not influenced greatly by $\mathrm{pH}$ showing a similar rate reaction in all cases $(\mathrm{pH} 5, \mathrm{pH} 7$ and $\mathrm{pH} 9)$. This effect was modified when the PCP degradation was done under a catalytic process, producing a higher degradation rate especially under acidic conditions.

Although the nature of the intermediaries produced during degradation of $\mathrm{PCP}$ in the presence of $\mathrm{MnO}_{2} / \mathrm{TiO}_{2}$ catalyst did not show significant differences regarding the degradation products identified in the non-catalytic ozonation processes; a higher production of mineralization products, particularly the amount of chloride generated in the catalyzed ozonation was observed.

The evaluation of ecotoxicity was studied on different biological species to reflect the potential damage that could result in humans. Catalytic ozonation not only allowed $>90 \%$ of degradation of PCP, but also showed a lower toxicity than the initial. Although a complex mixture of degradation products was produced, they were less toxic than the starting compound.

Regarding the toxicity tests using freshwater species such as Daphnia magna and plant species such as Lactuca sativa and Panicum millaceum, they were highly affected by the untreated PCP solution $(30 \mathrm{mg} / \mathrm{L})$, while the same species treated by simple ozonation and catalytic ozonation showed a better response demonstrating the efficiency of the toxicity reduction. There is a close relationship between toxicity and dechlorination of PCP. Accordingly, it was observed that the $\mathrm{MnO} / \mathrm{TiO}$ catalyst lowered the toxicity of the treated solution, thereby permitting a better growth of root and stem in the phytotoxicity tests.

\section{ACKNOWELEDGEMENTS}

The authors wish to thank Pedro Enríquez from the SAG (Servicio Agricola Ganadero- Chile) for his collaboration in the implementation of the ecotoxicological assay. Cristina Quispe thanks the Universidad de Talca for a Doctoral Grant and Proyecto fortalecimiento de líneas IQUD17PRO-010201010328 Universidad Arturo Prat. J.Cheel thanks the support of the National Program of Sustainability of the Czech Republic (ID LO1416). The technical assistance of Ivanna Bravo is gratefully acknowledged.

\section{REFERENCES}

1. Orton F., Lutz I., Kloas W., Routledge E.J., Environ Sci Technol., 43, 2144-2150, (2009)

2. ATSDR. Agency for Toxic Substances and Disease Registry, Toxicological Profile for Pentachlorophenol. Department of Health and Human Services, Public Health Service. Atlanta, United States, 2001.

3. Farré M.J., Franch M.I., Malato S., Ayllón J.A., Peral J., Doménech X., Chemosphere, 58, 1127-1133, (2005).

4. U.S. E.P.A. Environmental Protection Agency. Integrated Risk Information System (IRIS) on Pentachlorophenol. National Center for Environmental Assessment, Office of Research and Development, Washington, DC, 1999.

5. Oturan M.A., Oturan N., Lahitte C., Trevin S., J Electroanal. Chem., 507, 96-102, (2001).

6. EPA. Environmental Protection Agency. National Recommended Water Quality Criteria. Federal Register 57-60848, 1992.

7. Miháltz P., Pál F., Siska J., Duchateau F., Cent Eur J Public. Health., 8, $12-13,(2000)$

8. Luthe C.E., Chemosphere, 32, 2409-2425, (1996).

9. Xiao Xiao, Jianfang Hu, Ping'an Peng, Deyi Chen, Xinhui Bi. Environ Pollut., 212, 464-471, (2016).

10. Yoshida K., Nakanishia J., Chemosphere, 53, 427-436, (2003).

11. Pohl H.R., McClure P., De Rosa C.T., Environ. Toxicol. Pharmacol., 18, 259-266, (2004).

12. Von Gunten U., Water Res. 37, 1443-1467, (2003)

13. Esplugas S., Bila D.M., Krause L.G.T., Dezotti M., J. Hazard. Mater. 149, 631-642, (2007)

14. Dantas R.F., Contreras S., Sans C., Esplugas S., J. Hazard. Mater., 150, 790-794, (2008).

15. Jardim W.F., Moraes S.G., Takiyama M.M.K., Water Res., 31, 1728-1732, (1997)

16. Hong P.K.A., Zeng Y., Water Res., 36, 4243-4254, (2002).

17. Li X., Cao X., Wu G., Temple T., Coulon F., Sui H., Chemosphere, 109 71-76, (2014).

18. Matilainen A., Sillanpää M., Chemosphere, 80, 351-365, (2010).

19. Kasprzyk-Hordern B., Ziół ek M., Nawrocki J., Appl. Catal. B: Environ., 46, 639-669, (2003).

20. Chen K.C., Wang Y.H., Chem. Eng. Journal., 253, 84-92, (2014).

21. Chen Y.-H., Hsieh D.-C., Shang N.-C., J. Hazard. Mater., 192, $1017-$ $1025,(2011)$

22. Kasprzyk-Hordern B., Raczyk-Stanislawiak U., Swietlik J., Nawrocki J. Appl. Catal. B: Environ., 62, 345-358, (2006).

23. Rosal R., Gonzalo M.S., Rodriguez A., Garcia-Calvo E., J. Hazard. Mater., 169, 411-418, (2009)

24. Quispe C., Villaseñor G., Pecchi P., Reyes P., J. Chil. Chem. Soc., 51, 
1049-1052, (2006).

25. Villaseñor J., Reyes P., Pecchi G., Catal. Today, 76, 121-31, (2002)

26. Hunter R.J.J. Zeta Potential in Colloid Science, Principles and Applications, Academic Press, New York, 1981.

27. Villaseñor J., Mansilla H.D., J. Photochem. Photobiol., 93, 205-209, (1996).

28. APHA. American Public Health Association, Standard Methods for the Examination of Water and Wastewater. In Greenberg, A. E., L. S. Clesceri \& A. D. Eaton (eds), Washington, 1992.

29. Cutillo F., D'Abrosca B., DellaGreca M., Di Marino C., Golino A., Previtera L., Zarrelli A., Phytochem., 64, 1381-1387, (2003).

30. Cazar M.E., Schmeda-Hirschmann G., Astudillo L., World J. Microbiol. Biotechnol., 21, 1067-1075, (2005).

31. NCh2083. Norma Chilena Oficial Chile. Agua-Bioensayo de toxicidad aguda mediante la determinación de la inhibición de la movilidad de Daphnia magna o Daphnia pulex (Crustacea, Cladocera), 1999.

32. Pérez M., Torrades F., Domènech X., Peral J. J. Chem. Technol. Biotechnol., 77, 891-97, (2002).
33. Chang C.Y., Chen Y.H., Li H., Chiu C.Y., Yu Y.H., Chiang P.C., Ku Y Chen J.N., J. Environ. Eng. ASCE., 127, 908-915, (2001).

34. Staehelin S., Hoigne J., Environ. Sci. Technol., 16, 676-681, (1982).

35. Legrini O., Oliveros E., Braun A.M. Chem Rev., 93, 671-698, (1993).

36. Anipsitakis G.P., Dionysiou D.D., Gonzalez M.A. Environ. Sci. Technol., 40, 1000-1007, (2006).

37. Pecchi G., Reyes P., Sanhueza P., Villaseñor J., Chemosphere, 43, 141146, (2001).

38. Fernández-Alba A., Hernando D., Agüera A., Cáceres J., Malato S., Water Res., 36, 4255-4262, (2002).

39. Bozzi A., Dhananjeyan M., Guanaquillo I., Parra S., Pulgarin C., J. Photochem. Photobiol. A: Chem., 162, 179-185, (2004).

40. Santos A., Yustoa P., Quintanilla A., Garcia-Ochoa F., Casas J.A., Rodríguez J., Environ. Sci. Technol., 38, 133-138, (2004).

41. Azevedo E., Radler de Aquino F., Dezotti M., Appl. Catal. B: Environ., 54, 165-173, (2004).

42. Silva J., Iannacone A., Cifuentes L., Troncoso E., Bay-Schmith E., Larrain A., Ecotoxicol. Environ. Restor., 4, 10-17, (2001). 